Article

\title{
Nature-Based Deployment Strategies for Multiple Paces of Change: The Case of Oimachi, Japan
}

\author{
Rob Roggema ${ }^{1,2, *}$, Nico Tillie ${ }^{3}$, Greg Keeffe ${ }^{4}$ and Wanglin Yan ${ }^{5}$ \\ ${ }^{1}$ Cittaideale, Office for Adaptive Design and Planning, 6706LC Wageningen, the Netherlands; E-Mail: rob@cittaideale.eu \\ 2 Institute for Culture and Society, Western Sydney University, Parramatta, NSW 2150, Australia \\ ${ }^{3}$ Department of Urbanism, Delft University of Technology, 2628 Delft, The Netherlands; E-Mail: n.m.j.d.tillie@tudelft.nl \\ ${ }^{4}$ School of Natural and Built Environment, Queens University Belfast, Belfast, BT9 5AG, UK; E-Mail: g.keeffe@qub.ac.uk \\ ${ }^{5}$ Graduate School of Media and Governance, Faculty of Environment and Information Studies, KEIO University, \\ Kanagawa 252 0816, Japan; E-Mail: yan@sfc.keio.ac.jp
}

* Corresponding author

Submitted: 26 October 2020 | Accepted: 27 January 2021 | Published: 25 May 2021

\begin{abstract}
In this article a planning approach is proposed to accommodate different paces of urbanisation. Instead of responding to a single problem with a Pavlov-type of response, analysis shows that the transformational tempi of different urban landscapes require multiple deployment strategies to develop urban environments that are sustainable and resilient. The application of nature-based solutions, enhancing both human and natural health in cities, is used as the foundation for the design of deployment strategies that respond to different paces of urban change. The results show that urban characteristics, such as population density and built space is, partly, dependent on the underlying landscape characteristics, therefore show specific development pathways. To create liveable and sustainable urban areas that can deal holistically with a range of intertwined problems, specific deployment strategies should be used in each specific urban context. This benefits the city-precinct as a whole and at the local scale. Even small nature-based solutions, applied as the right deployment strategy in the right context, have profound impact as the starting point of a far-reaching urban transformation. The case-study for Oimachi in Japan illustrates how this planning approach can be applied, how the different urban rhythms are identified, and to which results this leads.
\end{abstract}

\section{Keywords}

deployment strategy; nature-based solutions; rapid urbanisation; resilience; transformation; urban change

\section{Issue}

This article is part of the issue "Planning for Rapid Change in Cities" edited by Karina Landman (University of Pretoria, South Africa).

(C) 2021 by the authors; licensee Cogitatio (Lisbon, Portugal). This article is licensed under a Creative Commons Attribution 4.0 International License (CC BY).

\section{Introduction}

Rapid urbanisation is a phenomenon which is mostly related to fast urban growth in developing countries. The Global Risks 2020 Report (World Economic Forum, 2020) looks at five areas that face particularly daunting challenges in the face of rapid and unplanned urbanization: 1) economic stability and social cohesion, 2) runaway climate threat, 3) accelerated biodiversity loss, 4) digital fragmentation and 5) health systems under pressure.
Urban environments, and not only the ones that change rapidly have increasingly to deal with these risks. It leads to Inadequate housing and the development of slums, poverty, poor sanitation and health and the spread of diseases, waste and pollution, and unemployment and urban crime (Bodo, 2019). Rapid urbanization threatens sustainable development (DESA, 2013) and has profound influence on mental health (Trivedi, Sareen, \& Dhyani, 2008).

The World Bank therefore aims to build sustainable cities and communities through an urbanization process 
that is green, inclusive, competitive, and resilient, contributing to the Sustainable Development Goal 11 (United Nations, 2020) implementation of the New Urban Agenda (United Nations, 2017) as well as the World Bank's goals to end extreme poverty and boost shared prosperity. It does so by focusing on four strategies: to help cities strengthen their planning systems and local capacities to better design, plan, and manage city assets and urban environments, to maximize multiple financial resources for cities through enhancing fiscal and financial systems, to promote territorial development in developing countries and cities and to build resilience to disasters and climate change.

Nature-based solutions is recently acknowledged as a potential effective planning approach to deal with a large part of the found issues in rapidly urbanizing cities. Rapid urbanization presents one of the most urgent challenges of our times. Cities must cope with poor air quality, heat island effects, increased flood risk and the frequency/severity of extreme events (e.g., droughts and heat waves), increasing crime and social inequity, poverty and degraded urban environments, amongst other negative consequences. Climate change adaptation and mitigation as well as sustainable management are therefore key challenges for cities in Europe and around the world. What must be developed therefore is a robust, wide evidence-base and reference framework of nature-based solutions-measures that mimic the complex features and processes of natural ecosystems-for local/regional city authorities and other policy and decision makers to increase climate resilience and address inclusive urban regeneration in cities (Lafortezza \& Sanesi, 2019). Nature-based solutions offers an innovative opportunity to optimise the synergies between nature, society and the economy (Faivre, Fritz, Freitas, De Boissezon, \& Vandewoestijne, 2017). They are capable of sparking social innovation in cities and accelerate the transition to sustainability. They do this by fostering innovative planning and governance, as well as new models for business, finance, institutions and the wider society (Wolfram \& Frantzeskaki, 2016).

The term 'nature-based solutions' is coined in the European Union and is an umbrella term for a number of different approaches that use nature to improve urban sustainability, like green infrastructure, green space, restoring rivers, ecosystem services, and ecosystembased adaptation (Mccormick, 2020). In the European Union research and innovation policy agenda (European Commission, 2015) the following description is given:

Nature-based solutions aim to help societies address a variety of environmental, social and economic challenges in sustainable ways. They are actions inspired by, supported by or copied from nature; both using and enhancing existing solutions to challenges, as well as exploring more novel solutions, for example, mimicking how non-human organisms and communities cope with environmental extremes. Nature-based solutions use the features and complex system processes of nature, such as its ability to store carbon and regulate water flows, in order to achieve desired outcomes, such as reduced disaster risk and an environment that improves human well-being and socially inclusive green growth. This implies that maintaining and enhancing natural capital is of crucial importance, as it forms the basis for solutions. These naturebased solutions ideally are resilient to change, as well as energy and resource efficient, but in order to achieve these criteria, they must be adapted to local conditions.

Hence nature-based solutions are seen as deliberate interventions seeking to use the properties of nature to address societal challenges.

Failing to provide a green, natural environment for humans leads to stress and illnesses. In urban areas without sufficient green space, increased levels of health problems are found. The lack of exercise in these urban environments presents children and adults with obesity (Epstein, Paluch, Roemmich, \& Beecher, 2007). More kids living in these precincts suffer from attention disorder at school (Flouri, Papachristou, \& Midouhas, 2018) or encounter ADHD and similar illnesses (Li \& Sullivan, 2016). The psychological problems amongst adults (Mennis, Mason, \& Ambrus, 2018; Thompson et al., 2012) cause higher levels of stress and in-house violence (Bureau of Crime Statistics and Research, n.d.). and higher crime levels compared to other areas. This evidence points at urban areas that are not the healthiest environment for humans. However, the solution is as simple as alien: to include more green space and nature in urban environments. Abundant, accessible and close to where people live. The 'extinction of experience' (Pyle, 1978) with "nature in childhood has a direct bearing on attitudes to the environment in later life. Children who spend time in green spaces between the ages of seven and twelve tend to think of nature as magical" (Tree, 2018, p. 294). Absence of noise pollution and bad air quality are associated with lower chances at Alzheimer's disease (Chen et al., 2017). The costs of health care for treating depression, anxiety, stress, phobias, suicidal impulses, obsessive compulsive disorders or panic attacks are estimated at $£ 12.5$ billion for the National Health Service, $£ 23.1$ billion for lost output of the economy and $£ 41.8$ billion for reduced quality of life and loss of life of humans, in the UK alone, and this can be alleviated by spending more time in nature (Bird, 2007). Contact with its natural environment, or biophilia, is therefore essential for a healthy population. Biophilia is the "rich, natural pleasure that comes from being surrounded by living organisms" (Wilson, 1984).

For a million years our survival depended on our ability to read the weather, the stars and the species around us, to navigate, empathize and cooperate with our environment. The need to relate to the landscape 
and to other forms of life-whether one considers this urge aesthetic, emotional, intellectual, cognitive or even spiritual-is in our genes. (Tree, 2018, p. 297)

Living in an environment loaded with stimuli, multiple forms of communication and information requiring attention demands constant 'directed attention' which is tiring and requires an enormous effort to block out distractions, resulting in symptoms of impatience, planning impairment, indecision and irritability (Kaplan, 1995). A natural environment offers indirect attention and a 'soft fascination,' providing a broad absorption demanding little effort and delivering plenty of space for reflection and mental recovery (Kaplan, 1995; Kaplan \& Kaplan, 1989). In our current urban environments this space is ever more compromised. The city lacks mental space in favour of physical spaces fulfilling urban programs mostly for economic benefits. A better balance in mental and physical components in developing cities would increase its resilience, creating a ReciproCity (Roggema, 2019, lecture note). Humans have the deep ability to respond to nature and to be calmed and reassured by particular natural settings and views, such as leafy plants and greenery, still or slow-moving water spatial openness, freestanding trees and unthreatening wildlife, providing the best recovery responses in modern-day stress tests and recover swiftly from stressful, energy burning fight-orflight responses (Ulrich, 1983; Ulrich et al., 1991).

Though in many policy documents sustainability, climate adaptivity and ecological principles are put forward as major guiding principles for shaping future societies, the current planning 'machinery' tends to respond in the same way, no matter what the context is. The main concern is that planning is incremental, path-dependent, while nature-based solutions require a break with past trends. The common planning approach takes a singular problem as the point of departure, solves the problem in a programmatic way then plans for it in a spatial way, allocating uses to areas. This implicitly neglects a range of developments and changes, such as climate change, biodiversity loss, social cohesion and a series of other urbanization issues. The question then is how well our planning system is capable to respond to rapid change whilst progressing to a sustainable nature-based and healthy future environment? Here, a major inhibitor of change must be overcome: 'Path dependence,' a concept where active memory conditioned by past decisions has a controlling influence on decision making. This concept leads to self-reinforcement that is detrimental to the creation of climate-sensitive infrastructure. Unless path dependence is broken through a combination of reforms, the shift towards the full adoption of nature-based solutions will not occur (Davies \& Lafortezza, 2019).

\section{Research Problem}

Rapid urbanization is often seen as a development that is typical for developing countries. This may, for a large part, true, but the phenomenon of urbanization is certainly not limited to the developing part of the world. In many cities in the developed world rapid urban change occurs also. However, the main difference is that in these cities often a long history of less rapid transformation can be witnessed. The historic periods of intermittent rapid and slow paces of transformation have succeeded each other, reflecting not only the time and technology to build cities but also the local landscape patterns. Planning approaches in many developed countries nowadays only react to one or few major problems and solve these in a linear way, often not taking into account the specifics of the grown urban areas. This lack of contextual responsiveness stands in the way of a sustainable urban development (Kropf, 2001) and the development of the city towards a natural urban environment is therefore compromised. This is caused by the beforementioned single problem focus, incentivised by the rapid change itself and the economic profitability or commercial feasibility, rather than taking ecology, culture and social wellbeing at the heart of urban planning. The process of redesigning cities to create more resilience (Folke et al., 2010; Gunderson \& Holling, 2002; Pickett, Cadenasso, \& McGrath, 2013), regenerative (Du Plessis, 2012; Girardet, 2014; Zari, 2018) and ecologically sound urban environments (Garcia \& Vale, 2017; Mostafavi \& Doherty, 2016; Sharifi, 2019) is often constraint by the slow machinery of governmental planning and market opposition (Davoudi et al., 2012; Lindblom, 1959).

The existing planning paradigm is predominantly linear, path-dependent and tends to repeat solutions for one issue or a specific problem. For instance, when housing shortage is a concrete motive dominating the planning process, after which the way the demand can be accommodated, for instance with the single focus on finding a location where the required amounts of houses can be built. Hereafter, the urban development process continues with establishing a land-use plan that makes the new use possible and an urban design prescribing how the new area will look like. Herewith, planning fails to respond holistically and accurately to a range of issues, often lacks engagement and support, and tends to repeat the solutions of the past. A thorough inclusion of ecological and green systems, structures and spaces is often absent or misplaced. By the time green and other sustainable solutions are agreed on, financed and ready to be implemented other changes happening to cities have caused a tremendous transformation. This means the originally well-thought solutions for a more sustainable city are solutions of the past rather than the future. Especially when the future is uncertain and potential changes are unprecedented, the response is too late, not fit for purpose and misses the objective it served initially. Therefore, an alternative, more adequate response is needed, allowing green, water, ecology, social cohesion, or the growth of food to keep pace with urban developments. Instead of lengthy planning processes, in which the solutions are compromised, and generally averaged 
out amongst all (hard) interests, responsive or anticipative planning would accommodate the transformational rhythms of each urban area by using a range of spatial strategies, each matching with their typical pace.

This calls for a more specific, an 'eco-acupuncturistic' planning (Houghton, Foth, \& Miller, 2015; Landry, 2005; Ryan, 2013) or Swarm Planning (Roggema, 2012) approach in which the nature of urban change becomes receptive to suitable nature-based solutions. A different pace of urban change should be reflected in the way spatial responses are undertaken. A slow transition, with small changes at spatial and timescales, would require small, temporal interventions creating microclimates of green space, while faster change, at larger time and spatial scales, asks for implementing structural green systems. This new planning approach is holistic and takes into account a spectre of problems, developments and changes, and connects these with the specifics of an area in terms of capacity and pace to change, adaptability, and grain of the urban fabric, formed by the landscape and its historic development (Figure 1). A way of planning that is capable of finetuning the relationship between the 'hosting' urban environment and the symbiotic spatial intervention that could increase the quality of green spaces so healthier and more ecological environments emerge.

The research question is therefore: How can accurately be responded to the different paces of urban change, in order to optimize the quality of life for humans and non-humans through nature-based solutions. The basis for this is found in the objective to provide an urban environment for people and the ecology to stay healthy long-term. In order to accurately respond to the context in which this can be achieved the intervention and the typology of urban transformation need to be matched. When the different types and paces of changing urban environments are understood, applica- ble deployment strategies can be developed and applied to designs for specific areas.

The Oimachi district (Figure 2), an urban environment south of the Tokyo Central Business District, is used as the case study area to analyse and test the new planning approach. At first view, the district can be characterised as an intensely used area. In contemporary urban design and planning literature, the intensity of an urban area is conceptualized as a vital characteristic to increase the sustainability and resilience, and is defined as the togetherness of diversity, proximity/compactness, connectivity and density (Cassaignau \& Jung, 2018; Dovey \& Symons, 2014; MVRDV, 2006; Rowe \& Ye Kan, 2014). The vitality in terms of a diverse, compact and dense urban environment might increase resilience and sustainability in social and economic terms, it may also deprive the possibilities for a green and healthy precinct. The interplay of intensively used spaces, relatively quiet zones or even neglected and underused voids (Jonas \& Rahmann, 2014; Rietveld \& Rietveld, 2014; Roggema, 2018) should therefore be embraced as a quality of a neighbourhood.

The overall characteristics of the Oimachi district reflect the intensity of the area. According to the Japan Statistics Bureau and Statistics Centre, in 2000 the population density for Shinagawa-ku was 142.87 persons/ha (Wendell Cox Consultancy, 2001), which is higher than Inner London at 113.52 persons per/ha and similar to Hackney at 147.90 persons/ha located at the fringe of the City of London (Greater London Authority, 2018). The Oimachi District, one of the five districts in Shinagawa City, has rapidly developed with the progress of industrialisation and urbanisation in the beginning of the 1900s. In December 2020, 104,893 people live on $4.73 \mathrm{~km}^{2}$ of land, a population density of 221.77 persons/ha. According to the city statistics in $2006,57.3 \%$ of the area is considered built-up, in which $39.3 \%$ for

\begin{tabular}{|c|c|c|}
\hline \multicolumn{3}{|c|}{ CURRENT PLANNING PARADIGM } \\
\hline Housing & $\begin{array}{l}\text { Program, search for } \\
\text { an area }\end{array}$ & $\begin{array}{l}\text { Land-use plan, } \\
\text { urban design }\end{array}$ \\
\hline Specific problem & Urban developmen & Spatial plan \\
\hline $\begin{array}{l}\text { Typology of urban } \\
\text { dynamic }\end{array}$ & $\begin{array}{l}\text { Full range of } \\
\text { changes }\end{array}$ & $\begin{array}{l}\text { (rapid) Deployment } \\
\text { strategy }\end{array}$ \\
\hline $\begin{array}{l}\text { Characteristic paces } \\
\text { of change }\end{array}$ & $\begin{array}{l}\text { Climate, ecology, food, } \\
\text { demography, health }\end{array}$ & $\begin{array}{l}\text { Area-specific spatial } \\
\text { interventions }\end{array}$ \\
\hline \multicolumn{3}{|c|}{ PROPOSED NEW PLANNING PARADIGM } \\
\hline
\end{tabular}

Figure 1. Proposed new planning paradigm. 


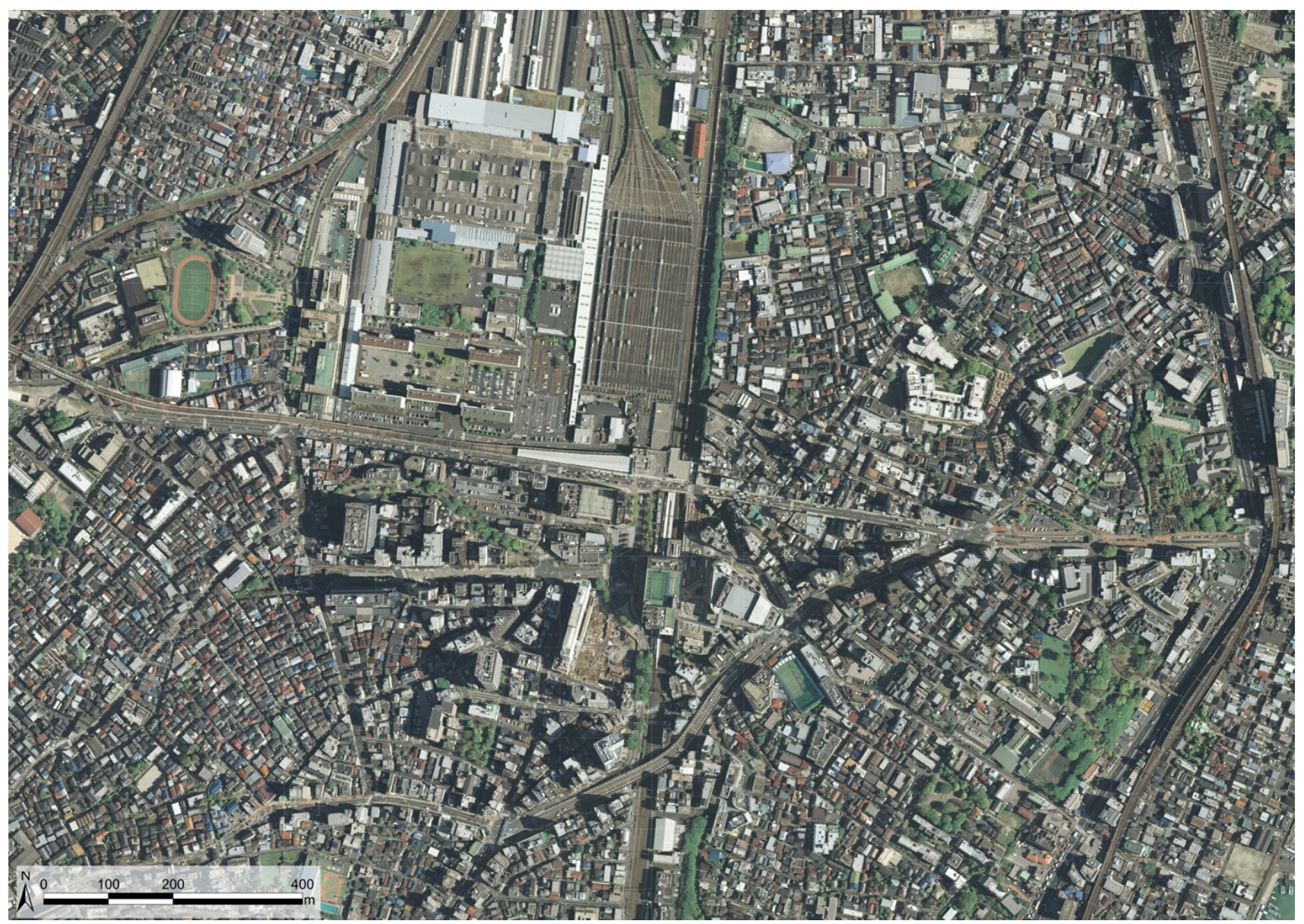

Figure 2. The area around Oimachi station, Japan. Source: Google Earth.

residential, $7.2 \%$ commercial, $31 \%$ office and industrial, and $15.8 \%$ green spaces. The amount of built area relatively to open or green spaces illustrate the sort of intensity of the precinct. In general, this is related to higher stress levels, mental illnesses and other health problems of its residents. The lack of green spaces and contact with nature is impacting the way humans behave. In order to increase tranquillity and stress relief, more green spaces are to be included the urban environment.

\section{Methodology}

Increasing the green environment in size and quality is the objective, then the deployment of ecological measures should be implemented at a pace the problems will not surpass them. When urban areas undergo a rapid change, alternative (green) initiatives will need to be rapidly deployed in order to keep up with the pace of change. Similarly, when areas undergo slower changes implementation of nature-based solutions can take a longer period and have a more structural character. Every area requires their own response. This is reflected in the applied methodology, which is an eclectic and intertwined combination of applicable action-research (Kindon, Pain, \& Kesby, 2007; Mclntyre, 2007; Selener, 1993) methods for spatial design, such as design char- rettes (Howard \& Somerville, 2014; Roggema, 2013). The design of the research approach is coherently brought together in six parts (Figure 3 and Box 1).

\section{Results}

The main finding of this research is the different urban areas each have a specific history, landscape basis, urban typology, transformation pace and appearance. In the Oimachi area we have found four fundamentally different zones (Figure 5): the fine-grain traditional neighbourhood (1), the modern urbanity (2), the old coastline (3) and the reclamation landscape (4). The existence of these zones is underpinned by analyses of the urban mapping, landscape basis and urban sensing.

\subsection{Urban Types}

Table 1 reflects the differences between the four urban zones in population density, the amount of built-up area and existing green spaces. The scale of each zone is also different. The roji-area (1) is characterised by a relative high population density, small scale built-up entities, and small public spaces with little and small areas of green (Figure 6). It has a mixed use of residential, small businesses and restaurants. The modern urbanity zone (2), 


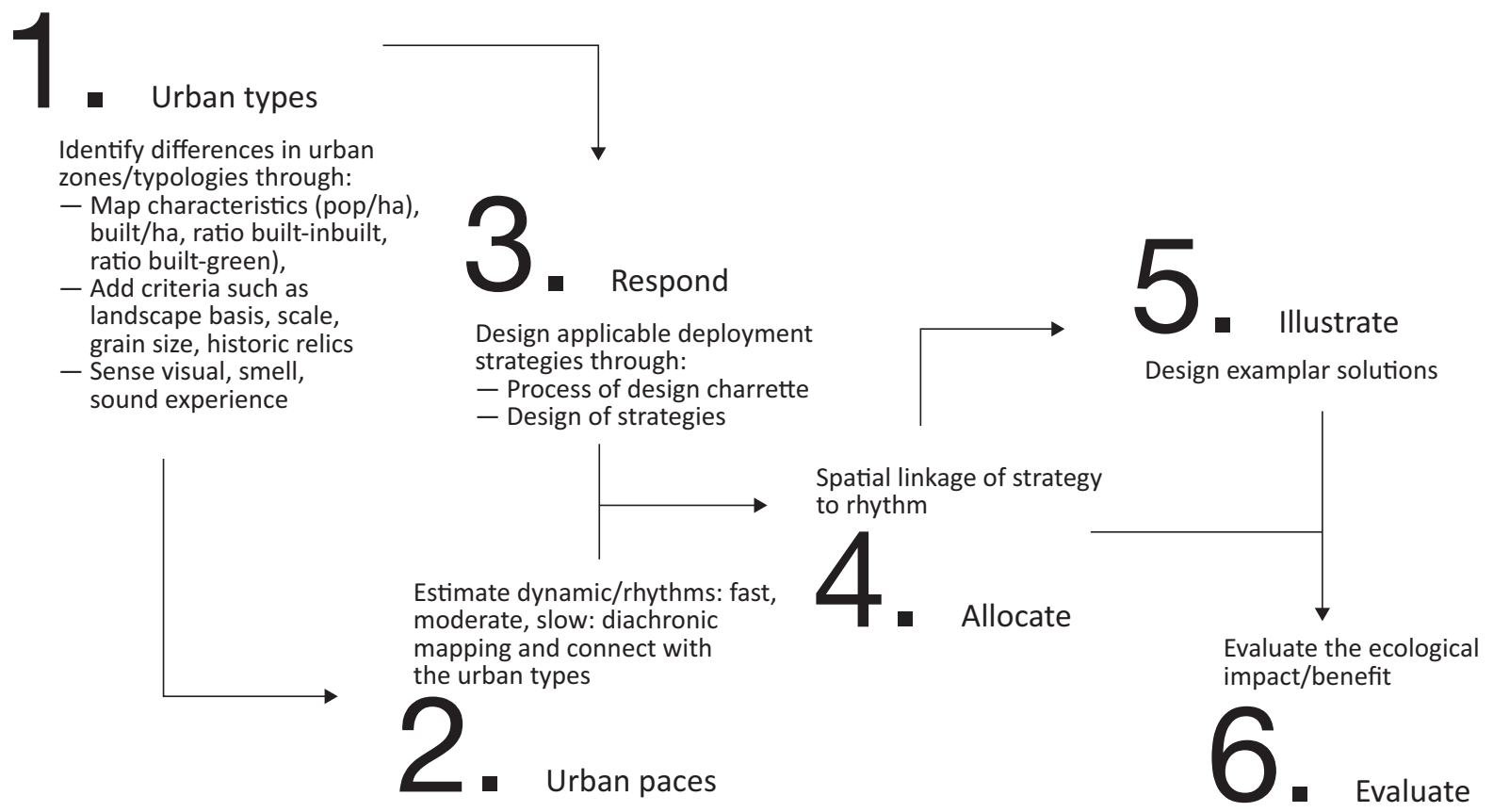

Figure 3. Methodology used for constructing a rapid deployment strategy for Oimachi.

Box 1. Methodological steps.

1. Urban types:

- The characteristics of the area (pop/ha, built area/ha, ratio built-unbuilt, ratio built-green space) are mapped (Dennis et al., 2018; Vanderhaegen \& Canters, 2017);

- Additional aspects such as landscape basis, scale, grain size, historic relics are identified using landscape layer mapping (Kuitert, 2013; Pinzon Cortes, 2009); and

- Sensing urban experiences (Borer, 2013; Degen \& Rose, 2012; Diaconu, Heuberger, Mateus-Berr, \& Vosicky, 2011; Pink, 2007; Rapoport, 2016), such as sound, view and smell are collected through site visits and wandering the precinct.

2. Urban paces: For every area its dynamic/rhythm is determined through a diachronic spatial mapping analysis (Cialdea \& Maccarone, 2012; Van Bree \& Kessels, 2014) to illuminate slow and fast variables, the dynamics of change, cycles of resilience (Gunderson \& Holling, 2002), adaptative capacity (Brooks, Adger, \& Kelly, 2005) and transformation (Garcia \& Vale, 2017; Pickett et al., 2013; Roggema, 2012), to understand processes of emergence (Goldstein, 1999; Krugman, 1996). Subsequently the layer-approach is applied to identify the different timeframes or rhythms (De Hoog, Sijmons, \& Verschuuren, 1998; Frieling et al., 1998) and distinguishing higher and lower dynamics of specific land-uses (Sijmons, 1992) to determine the changeability/rhythm of the urban layers (Roggema, Van den Dobbelsteen, Biggs, \& Timmermans, 2011). The urban paces are then linked to the identified urban types in step 1.

3. Respond: In response to the findings in steps 1 and 2, applicable deployments strategies are designed in a creative, collaborative process. This process is based on the design charrette methodology (Condon, 2008; Lennertz \& Lutzenhiser, 2006; Roggema, 2013), an intensive form of action research, in particular useful when problems are tense and complex. The design charrette process involves a range of stakeholders, experts, professionals, citizens and businesses in a creative way. For example, one of the methods used is the building of plasticine models to decrease conflicts of interest and expel rationalised vested interests from the discussion. The models (Figure 4) represent the collective results as strategic outcomes of the charrette by using research by design methodology (Hauberg, 2011; Milburn \& Brown, 2003; Roggema, 2016; Rosemann, 2001; Swann, 2002) that are supported by all participants. This allows for the exploration of uncharted territory and develop new and innovative design solutions.

4. Allocate: The fourth stage in the research process allocates the typical strategies to suiting areas. The pace of change (step 2) is herewith connected to research by design outcomes (step 3).

5. Illustrate: Spatial designs are subsequently conceived as an illustration of the applied strategies.

6. Evaluate: In the final stage the benefits for the quality of urban green and ecology of the design-solutions are assessed. 


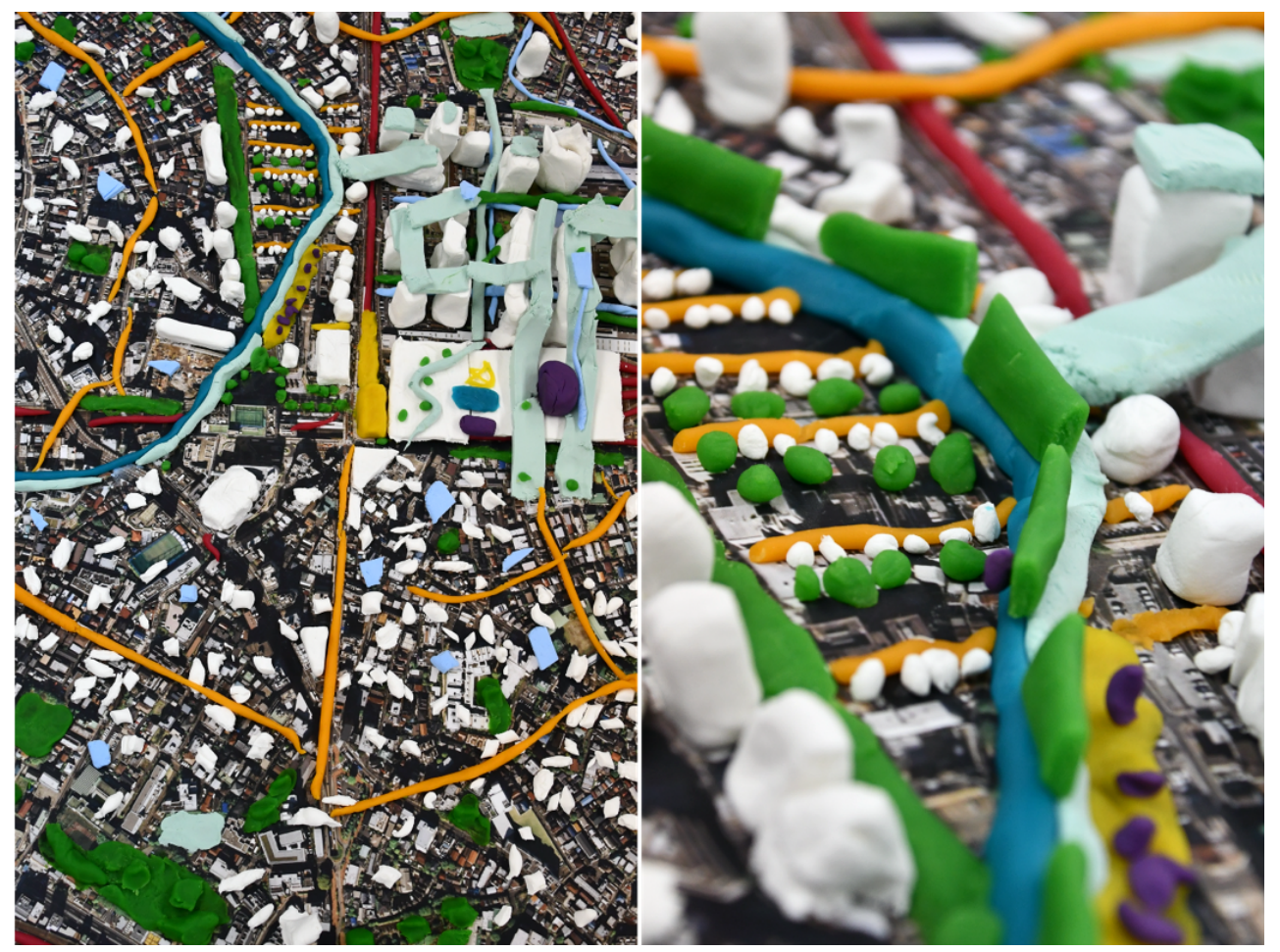

Figure 4. Plasticine modelling of the collective design propositions.

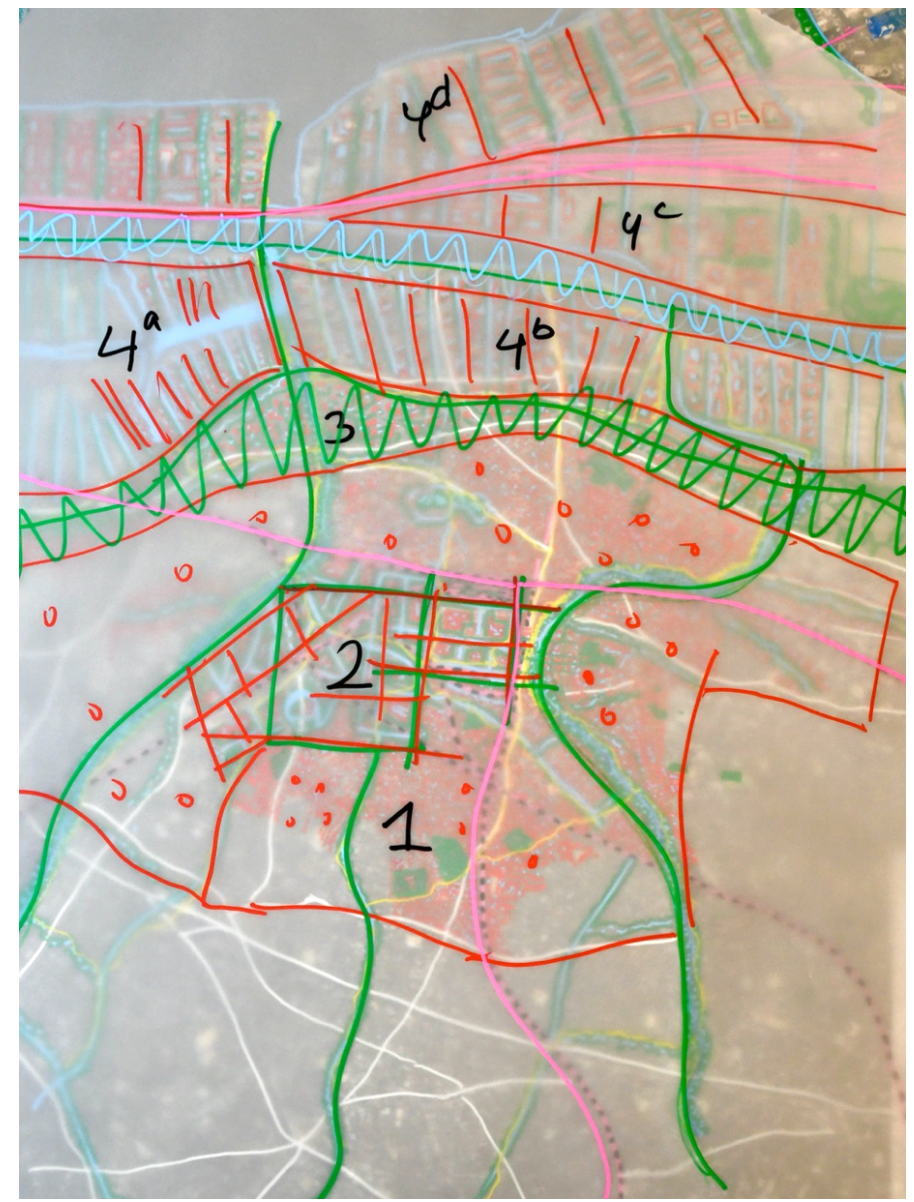

Figure 5. Four urban landscape typologies in Oimachi. 
Table 1. Urban characteristics.

\begin{tabular}{llllll}
\hline & $\begin{array}{l}\text { Oimachi } \\
\text { district }\end{array}$ & $\begin{array}{l}\text { Fine grain- } \\
\text { roji area (1) }\end{array}$ & $\begin{array}{l}\text { Modern urbanity- } \\
\text { around station (2) }\end{array}$ & $\begin{array}{l}\text { historic (3) } \\
\text { Coastal ridge- }\end{array}$ & $\begin{array}{l}\text { landscape (4) } \\
\text { Reclamation }\end{array}$ \\
\hline $\begin{array}{l}\text { Population persons/hectare } \\
\begin{array}{l}\text { Built form/hectare } \\
\text { (number of buildings) }\end{array}\end{array}$ & 213.94 & 346.94 & 203.61 & 242.24 & 96.04 \\
Ratio built_open space (unbuilt) & 40.52 & 57.64 & 28.66 & 41.65 & 3.91 \\
Ratio built form-green space & $8.80 \%$ & $2.64 \%$ & $2.26 \%$ & $37.29 \%$ & $64.54 \%$ \\
Scale/grain & & $\begin{array}{l}\text { Small scale, } \\
\text { fine grain }\end{array}$ & $\begin{array}{l}\text { Large scale, much } \\
\text { open space with } \\
\text { large grain }\end{array}$ & $\begin{array}{l}\text { Average scale, } \\
\text { fine grain }\end{array}$ & $\begin{array}{l}\text { Extra-large scale, } \\
\text { large logistics }\end{array}$ \\
\hline
\end{tabular}

mainly around and north of Oimachi station has a relatively low population density in a larger scale urban grain, with larger sizes of public spaces and more and larger green areas (Figure 6). The use is related to transport and leisure. The old coastal ridge (3) has an average population density in a small-scale urban environment with relatively spread-out green spaces. The area is dominated by residential. The reclamation landscape (4) has a very low population density and is characterised by very largescale building blocks for logistics purposes. Green spaces are often left-over space.

The population density has changed dramatically during the first part of the 20st century, when the area urbanised. The density jumped from nearly 8 persons/hectare in 1890 to almost 200 in 1940 (Figure 7).
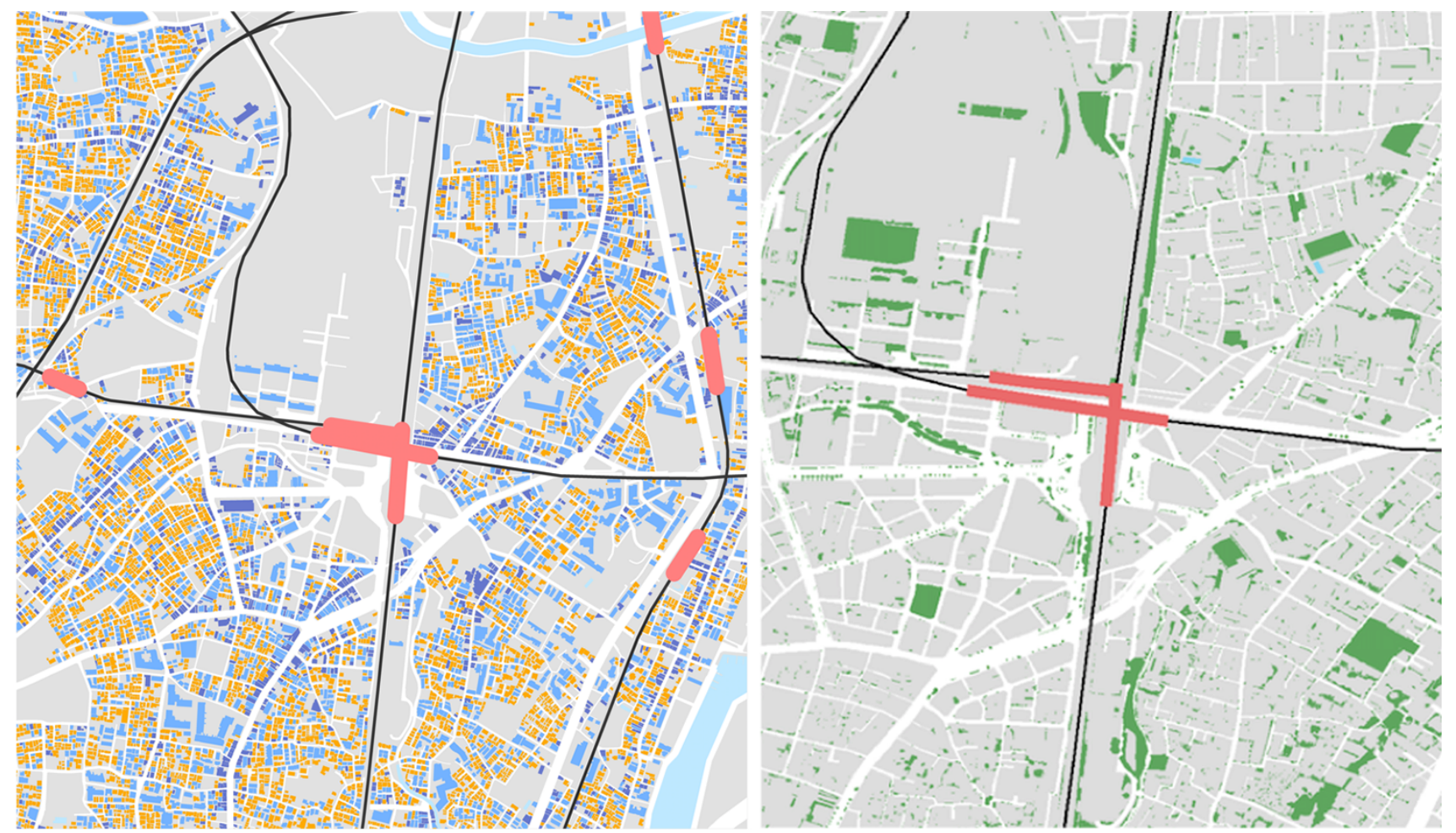

Figure 6. Contrast in scale and green spaces between the roji area and modern urbanity. Source: Courtesy of KEIO University and Tokyo Prefecture. 

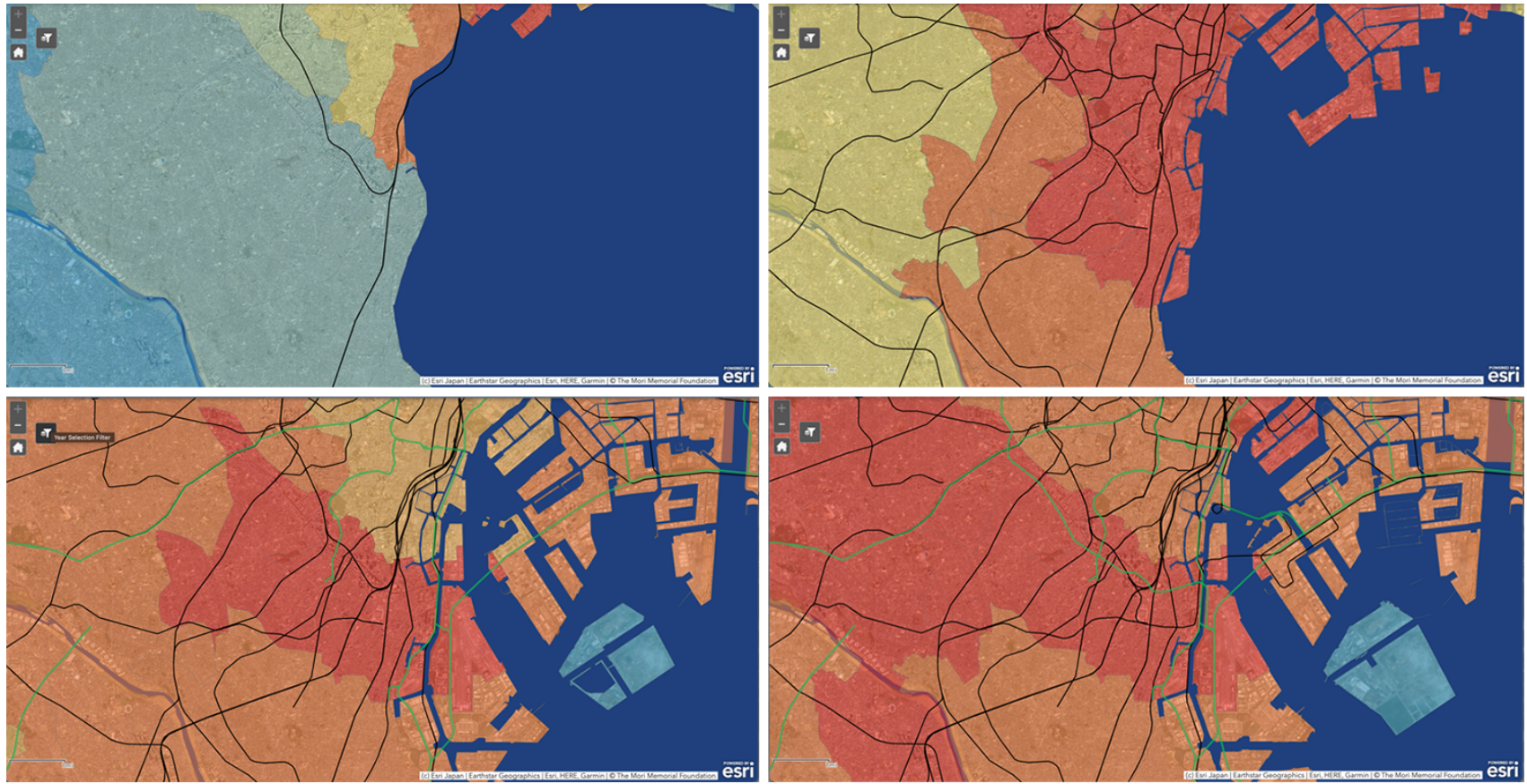

Figure 7. Population density (persons/ha) in 1890 (7.68), 1940 (198.4), 1990 (152.45) and 2015 (171.0). Source: Institute for Urban Strategies (2020).

as a complex urban area where the clarity in the order of urban spaces is limited and functionality is seemingly inefficient. The larger plot sizes in the landscape are located on the lower grounds near the waterways where they were used as grasslands and rice-paddies. Their larger scale has led to mono-functional urban entities that are currently spread out near the railway lines forming the modern urbanity area (2). The coastal ridge (3, Figure 8 , right) is the former coastline and can still be seen as the most dramatic drop in elevation in the entire area. The rocky underground caused a perfect basis for the first settlements as here people could build homes easiest and were safe for any risk from the sea. The sturdy underground provides difficult conditions for
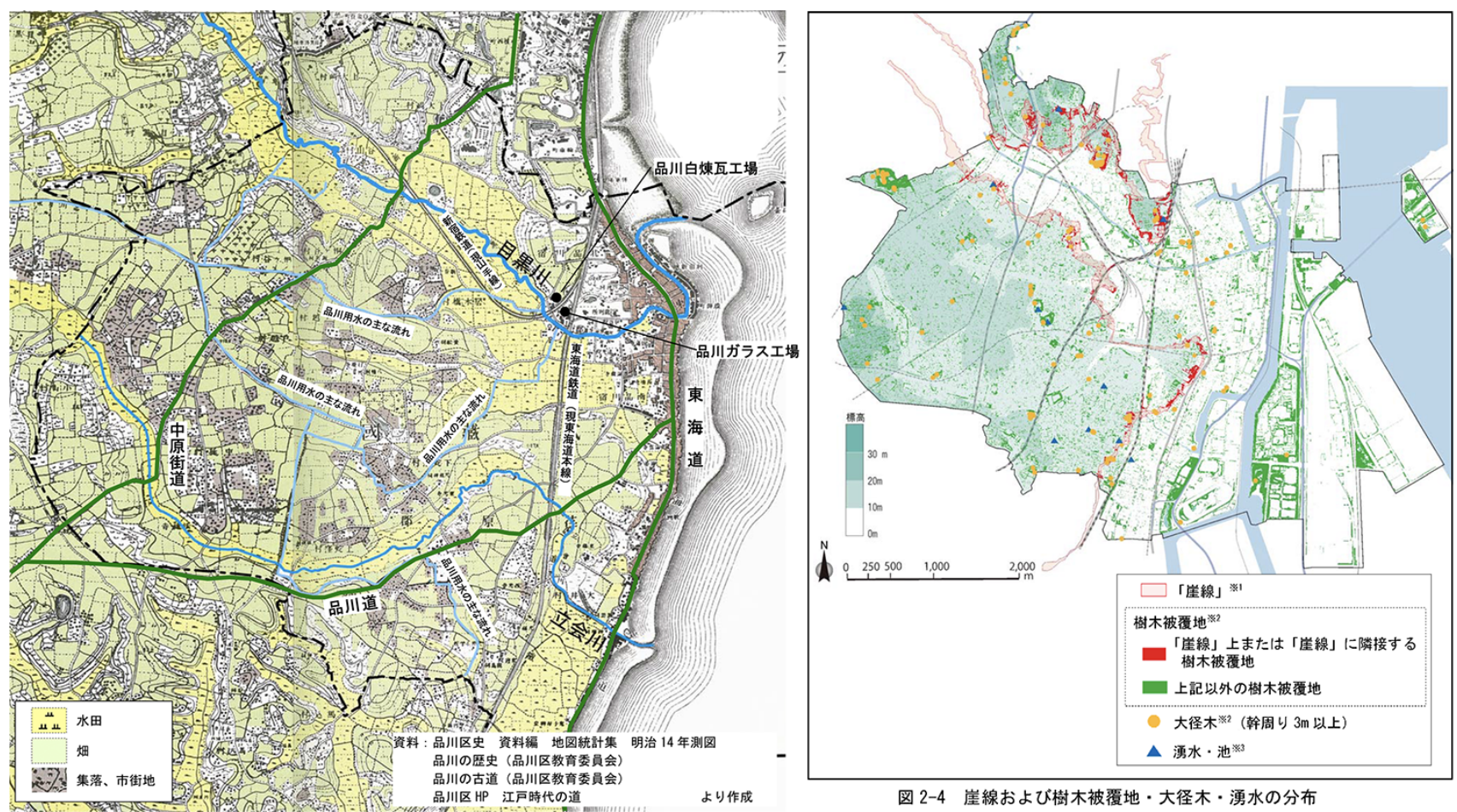

Figure 8. The Oimachi landscape in 1881 (left) and green cover in current urban environment, depicting the old ridge in red, large trees in orange and wells in blue (right). Source: Courtesy of the City of Shinagawa. 
growing, as it takes effort and time for a tree to mature. Once this however is achieved the rewards is likewise: a rich and sophisticated enduring green environment in which a high-quality residential settlement is embedded. The landscape of the 'to be reclaimed' land (4) from the Tokyo bay consists of reclaimed land as a dewatered polder system or gained through sand suppletion. It had to be won from the water in well organised units, efficiently reclaimed by the available techniques at the time. This urban area therefore is artificial, rational and, depending the time of reclamation, of a large or very large scale. The economic drivers are dominant hence water and green are submerged in the local urban activities, and only appear (or left over) if the space is not usable for an economic purpose.

The urban characteristics and landscape specifics are supported by the actual sensed atmospheres when wandering the city at different times of day and week. The roji-area is a tranquil and intimate area feeling enclosed. At lunchtime and in evenings it is buzzing with activity, but other times of day one can hear people talk occasionally. During weekends it is a quiet place. Where weekdays are full of food smell, the weekend smells are dominated by cleaning and washing odours. The modern urbanity area in the direct vicinity of the station, is busy during peak hours, even in the late evening. The rest of the day it is unexpectedly quiet, near empty, during the night it turns into a desolate area. The weekends are buzzing with families and young people seeking thrills and entertainment. The active periods of the week the gasoline smells reflect the dominance of traffic, while during weekends the smell of barbeques is apparent. The area is open and exposed to views, implying a lack of privacy, and the weather. The coastal ridge is tranquil with abundance of old trees that generate a green smell. It is a quiet place, stable during day/night, week/weekend. It offers secluded living where people can hide and withdraw from public life. The reclaimed landscape is a noisy place, full of industrial activities. On weekdays it is a constantly active area, during the day and (most of) the night, when it smells like oil and harbour. The weekends show a different side when the area is quiet and desolate, and it smells fish and sea.

\subsection{Urban Paces}

Through diachronic mapping the estimated dynamic or rhythms of urban areas are illuminated. To identify the 'pace' of change, the built environment is mapped in nine different periods, from 1909 until 2005 (Figure 9). This shows what changes and persists in the urban space.

The roji-area appears on the map just after 1890, and the basic urban pattern has not changed significantly ever since the rural landscape transformed in an urbanised pattern (Figure 10, upper). The built structures are only disturbed by large infrastructure interventions such as railway lines and some broad roads. The majority of roads and alleys however remain unchanged since the neighbourhood was conceived. The pace transformations take place in this area are very modest and slow. The modern urbanity area around Oimachi station has a different dynamic. The station itself made its appearance, and is subsequently expanded, the area around the railway tracks is constantly reconfigured with new
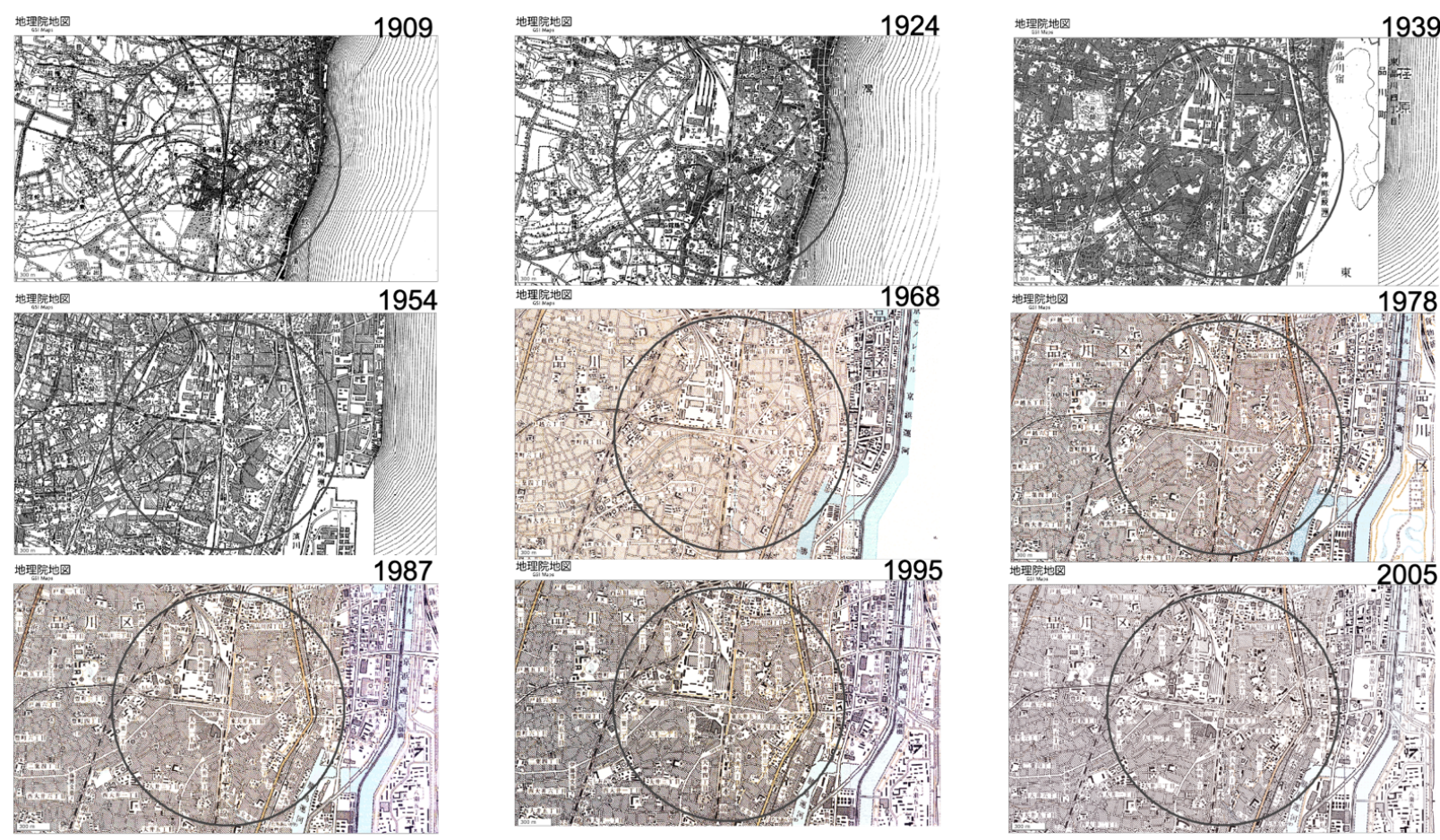

Figure 9. Diachronic mapping 1909-2005, indicating urban changes. Source: Courtesy of the Geospatial Information Authority of Japan. 

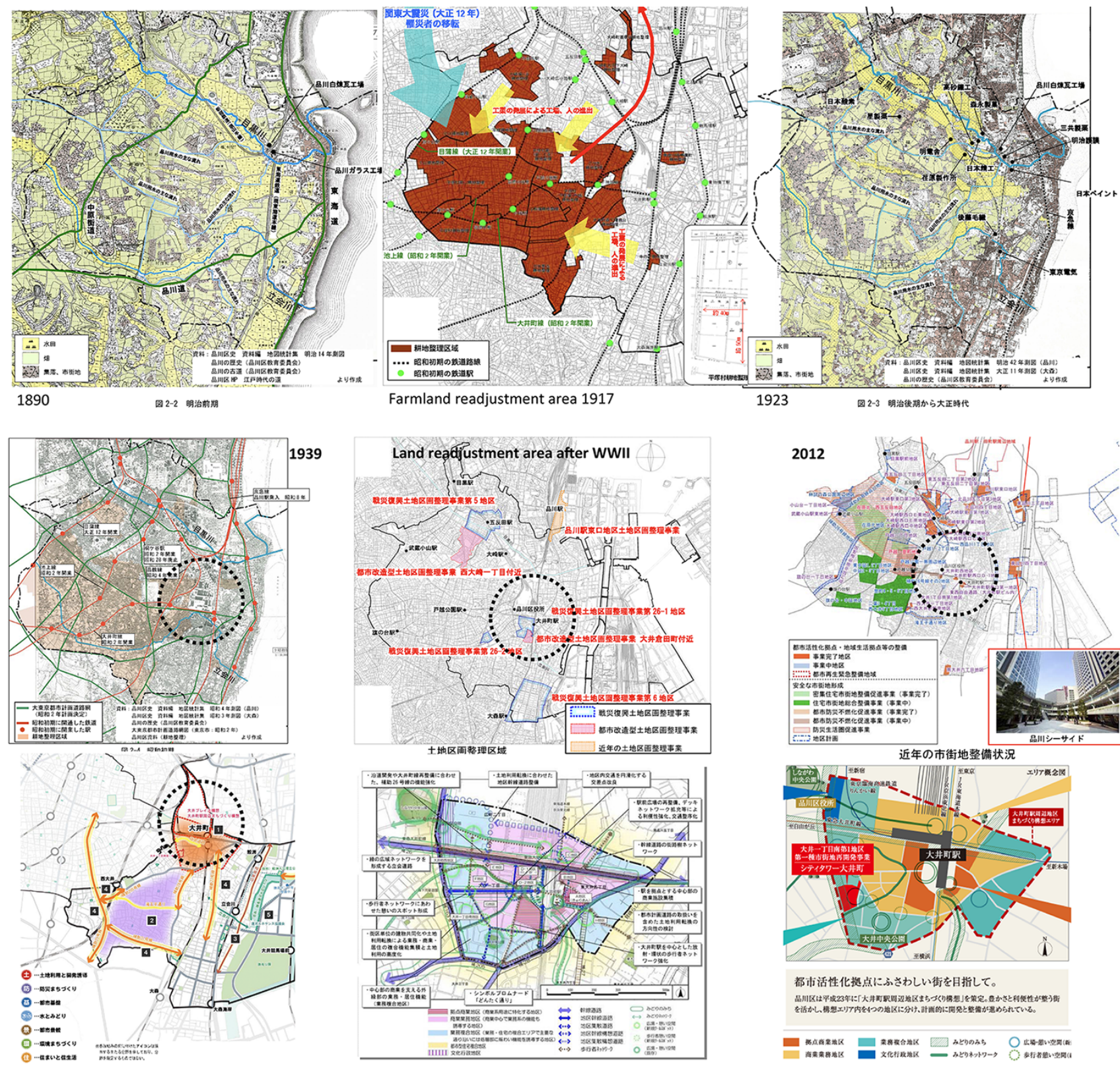

Figure 10. Period of change in the first decades of the 20st century: from a rural to an urban landscape (upper three maps) and permanent dynamic conditions around Oimachi station (lower six maps). Source: Courtesy of the City of Shinagawa.

buildings open spaces and changing uses (Figure 10, bottom). Up until 2015 new buildings are added, which differ in size and use. This makes this area where the fastest transformations have taken place. The coastal ridge is the most stable area. Ever since its origin the homes and buildings hardly changed, and the infrastructure remains identical and at the same place. This makes this area the slowest transforming area. The first pieces of the reclaimed landscape appear on the 1940 map, while larger expansions are constructed during the 1960 and subsequent decades. The larger blocks and orthogonal structure of water and infrastructure lead to an unchanging framework within which built structures once in a while are replaced. The change of pace in this area is, after the land is reclaimed relatively low.
The paces the four areas are changing can be linked to the urban types and their raison d'être (Table 2). These linkages are used to define the applicable responses.

\subsection{Respond}

To create applicable responses or deployment strategies the type intervention needs to be aligned with the area. Applicability of the intervention is not straightforward and therefore spatial principles have been developed that are better suited to the pace of transformation in an area. Rapid strategies are deployed when the transformation pace is slow and more structural, slower deployments are required when the changes are fast as these areas benefit from enduring green structures. 
Table 2. Relation between density, scale, landscape and pace of change.

\begin{tabular}{lllll}
\hline & Population density & Scale \& block size & Landscape basis & Pace of change \\
\hline Roji & Very high & Very small & Old farmland, higher grounds & Slow \\
Modern urbanity & Low & Large & Grassland close to watercourses & Fast \\
Coastal ridge & Moderate & Small & Cliffs of the old coast & Very slow \\
Reclaimed landscape & Low & Very large & Artificially made land & Moderate \\
\hline
\end{tabular}

Rapid deployment principles (Figure 11, left) that have been created for stable urban precincts to deploy quickly and at a small scale. These principles are used to incentivise developments, to ignite a process towards green ecological urban environments within stable contexts. Moderate deployment principles (Figure 11, centre) take a longer time to implement but can be applied in the foreseen future, periods within the next 5-10 years. These interventions are suitable for environments that are changing at moderate paces. Structural deployment principles (Figure 11, right) are deployed in rapid changing environments. These urban contexts require a stable intervention, which might take some time to implement but give the area a stable green ecological framework within which spatial developments of different dynamic can be accommodated.

\subsection{Allocate}

Understanding the urban types and their spatial rhythms makes it possible to allocate the deployment principles accurately. For each of the four urban landscape types a series of principles are deemed suitable (Figure 12). The allocated design principles in roji area mainly focuses on adding extra qualities and productivity by enhancing existing and introducing new green spaces, ecological areas, small-scale places for the growth of food, water storage and purification, energy generation and adding small shops and restaurants. The modern urbanity area can be enriched through additional residential, rooftop farming, water recycling systems, and connected pub- lic green spaces. This area offers the opportunity to collectively generate local renewable energy and improve ecological connections within and outside this area. The coastal ridge forms the main ecological gradient, connecting the higher landscape with the reclaimed land by establishing new and enlarging current ecological corridors. In the reclaimed landscape itself the hidden blue-green structures can be re-introduced and be emergently brought back in the urban landscape, following the orthogonal parcelling of the polder-works.

\subsection{Illustrate}

The proposed planning approach aims to provide a holistic, site specific response to different paces of transformation. It brings together a range of problems impacting urban life, such as climate change, demographic change and liveability. The historic development trajectory in slow or fast modes is used to identify the most suitable spatial responses, aiming to create a sustainable and resilient urban environment through nature-based solutions. These responses are created as deployment principles, which, in combination, are applied to a concrete area. The benefits are multiple and range from improving biodiversity, enhancing urban climate, increasing productivity and generating local resources. This has profound effects on the liveability, health and economic well-being of the local residents.

The design illustrates the interconnectedness of spatial propositions at two scales, the entire precinct and the local public spaces, such as roji's, watercourses or
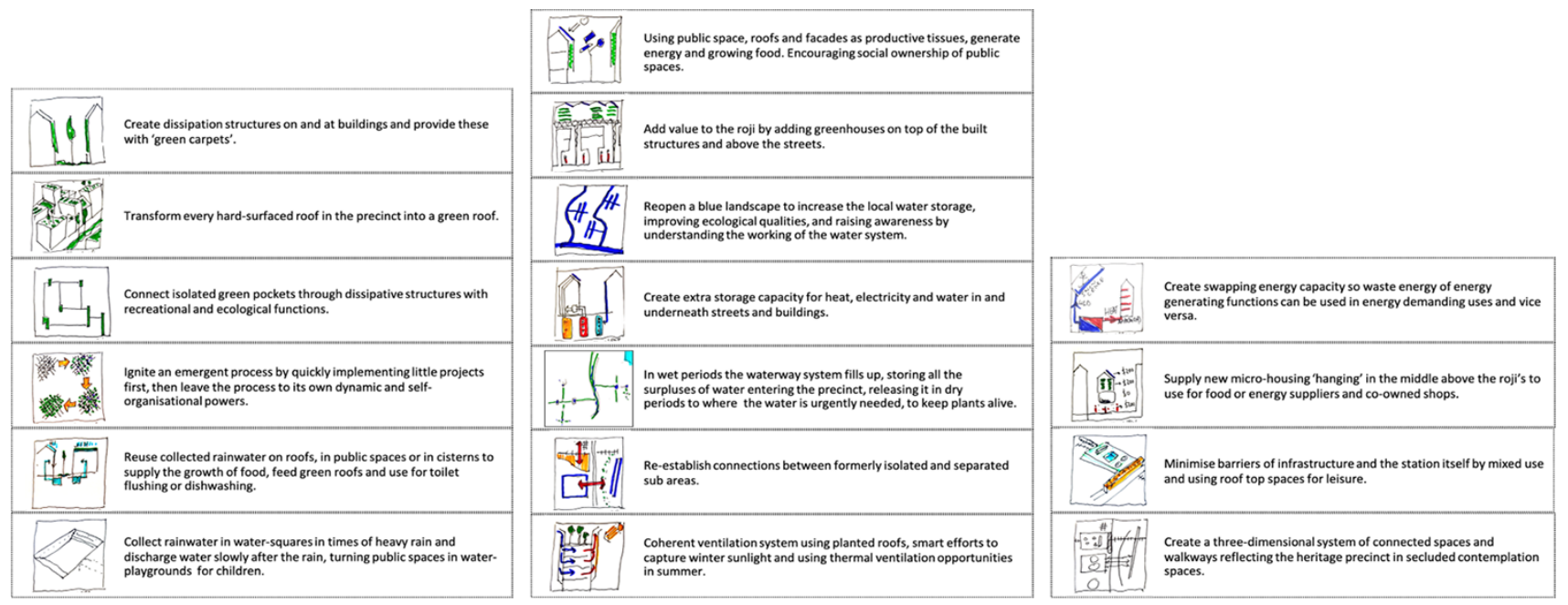

Figure 11. Spatial principles for slowly, moderately and rapidly transforming environments. 


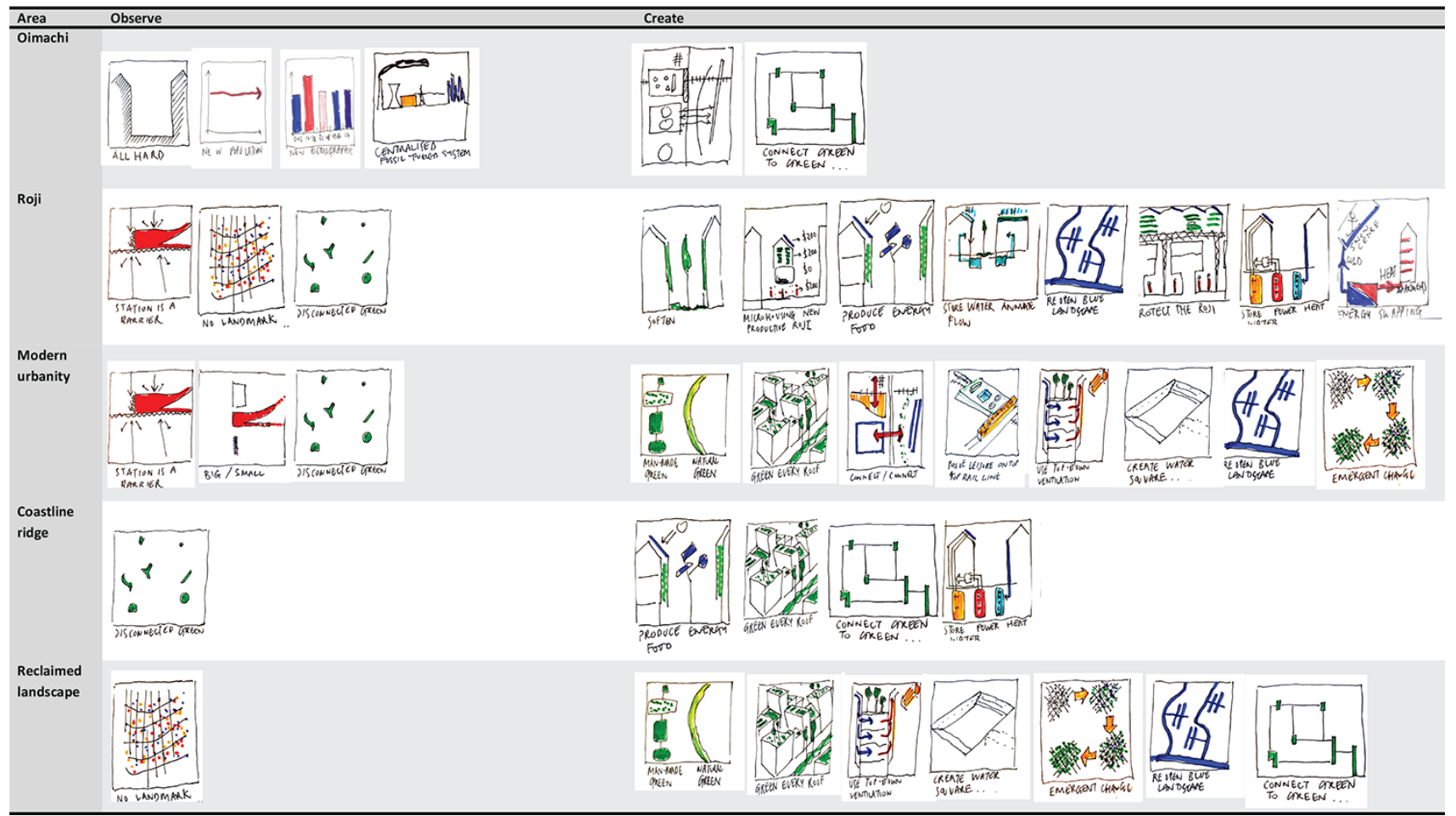

Figure 12. Allocation of deployment principles to specific urban areas.

squares. At the precinct scale the main watercourses are re-established as open, publicly accessible spaces (Figure 13) with ecological added value. It allows for a greater connectedness of green spaces, urban integration and an improved urban climate. These two water- ways are connected by the orthogonal system in the urban modernity area, creating a spatial framework for this rapidly changing environment. Within this basic framework of the lower dynamic uses such as green, ecology and water, new and temporal uses with higher

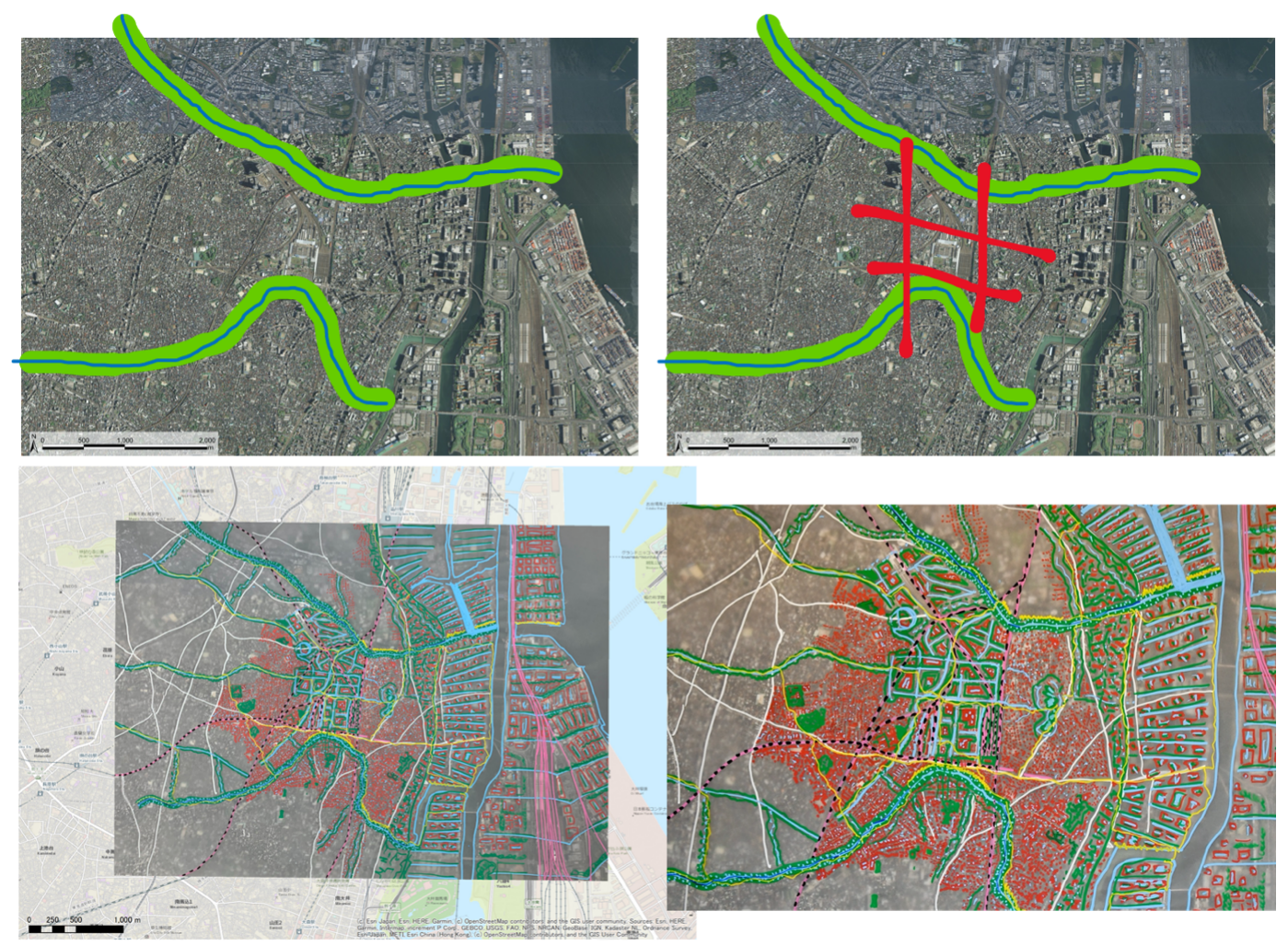

Figure 13. Urban design in consecutive steps. 
dynamic, can be embedded without compromising the overall quality and loss of resilience and orientation.

Within the precinct framework the blue-green connections are intensified at the lower scale. The deployment strategies relate the large spatial framework with smaller scale environments. The visualisations show the transformation of the current situation towards a green and productive urban environment (Figure 14). In and above small streets additional productive spaces are created and integrated in existing buildings. Currently hidden waterways are transformed into ecological valuable and clean water corridors that are attractive to the residents.

\subsection{Evaluate}

The ecological values of the different deployment strategies are also beneficial for the 'health' of the (urban) ecosystem itself, its abiotic elements, habitats and species it can potentially accommodate. In a natural ecosystem the finely tuned relations between species and with their abiotic environment makes that each species as well as some key abiotic elements (rivers, soils/surfaces etc) have an ecological value within that system. Species diversity increases the resilience and value of the natural ecosystem (Odum \& Barrett, 2005). With losing key species an ecosystem as well as its additional values can collapse. Agriculturally productive urban landscapes can be mixed with ecological qualities (Roorda et al., 2011). The rapid deployment interventions provide building blocks for an urban ecosystem restoration strategy. By introducing new green blue 'patches' and 'corridors' a new green blue 'matrix' emerges in Olmachi. The corridor-patch-matrix theory (Forman, 1995) can be applied at many scales. Each type of intervention provides certain conditions and has specific characteristics such as size, shape, location,
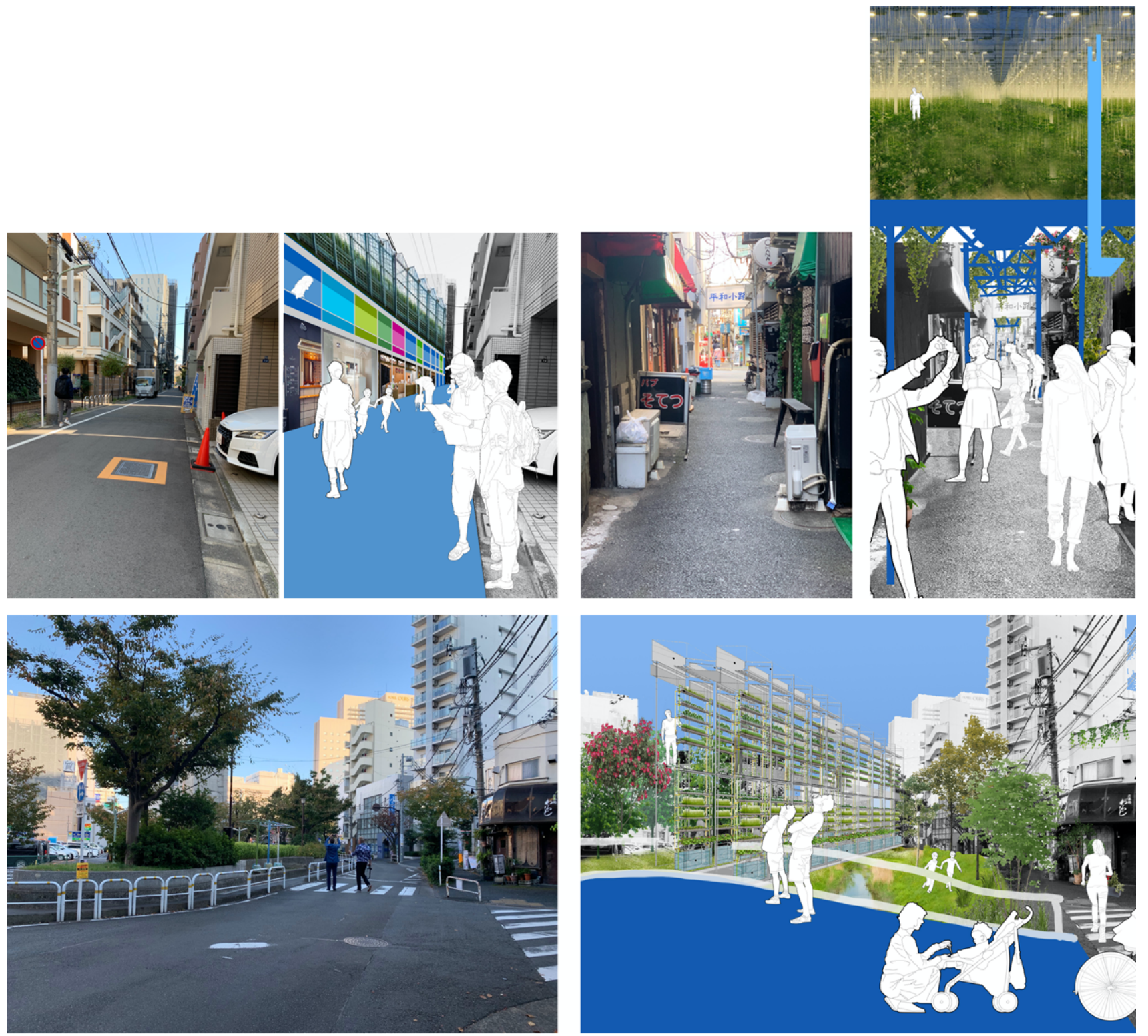

Figure 14. Design propositions for local public spaces. Source: Courtesy of Bill Galloway. 
species level and so on and with that has a certain ecological value. Below the water system and the four typologies will be discussed.

The importance of restoring the ecological value of the rivers and water system lies in the reconnection it establishes between the mountains, the low-lands and the bay area. Oimaichi, located in the lowlands is a part of this larger system. Also, at a lower scale the new waterways are a fundamental corridor, providing wet-dry, and nutrient rich/poor gradients resulting in different habitats and related species. Hence, ecological values will further increase.

In the roji area, pots and pans are often used to grow vegetables and flowers at the front door. Throughout the neighbourhood this forms a valuable green matrix for other plants, insects, birds and small mammals. Introducing a large greenhouse on top of these neighbourhoods would block a lot of sunlight and alternatives for this small-scale gardening, such as rooftop and façade gardening should be found to prevent that ecological values will decrease. The modern urbanity area of the Oimachi station will densify but will also give space to new parks and connections at ground level to the river system. New buildings will be provided with green facades and roofs and will connect to each other and to ground level. This area provides the opportunity to construct green-blue patches and corridors at building, street and neighbourhood scale. The ecological value can be high although an overall long-term strategy for this area is required to guide individual developments. The old coastal ridge still has an ecological gradient from the hills to the lower reclaimed lands of the bay. There are still some old trees and green structures forming the basis for new patches and corridors. The reclamation landscape allows for introducing new waterways and connections to the bay. Wet-dry and fresh-saltwater gradients provide conditions for new habitats. Ecological values increase as they provide many species with new habitats and breeding spots such migrating species of fish and birds. As this area is a working port, hybrid functions (hard and soft quays for example) have to be introduced. Principles of nature-based urbanism need to be extracted on site (Tillie, 2020).

\section{Conclusion}

In this article a new planning approach is proposed which holistically links the entirety of urban problems with the path-dependency of transformational paces. Where traditional planning often preludes to one, familiar, response to a single problem, including the pace of change in the planning process prevents a mismatch of spatial solutions for different urban contexts. Therefore, it is concluded that when the type of deployment strategy is related to the pace of change of the urban area, a more suitable spatial response is provided.

The proposed planning approach consists of a process in which firstly the urban characteristics are iden- tified to understand the context of operation, which is then linked to the typical pace of change in different areas. Once this context is understood a creative design process is organised to develop the responsive strategies that fit the urban specifics and rapidity of change. The range of possible deployment strategies are then used in a concrete area to design solutions at precinct and local intervention scales.

This planning approach improves urban sustainability in different ways. First, small deployment strategies take large effect. Especially in denser urban contexts there is often not much space for extended ecological or sustainable urban redevelopment. An incentivised, deployment strategy offers a way to implement small interventions enforcing a crucial change that start an emergent development towards a more liveable environment. Second, improving green and ecological values for human and biological health. Green and ecological transformation add to the overall ecological value of an area, especially when these areas are connected with each other. Implementation of deployment interventions fitting the changeability of urban precincts that is linked with each other will lead to an entire network of plants, animals and humans. Third, applying deployment strategies that fit the dynamics in a certain area resonate with the residents and changes will therefore be higher valued and more appreciated. For people's daily living conditions this means a difference between a hostile, concrete and unpersonal walk to the train station or an enjoyable stroll in between the clean and green. Applying the right deployment strategy changes the mechanism. And finally, introducing a deployment strategy, or a range of strategies, in an area starts a process of physical and psychological change. It forms the starting point for spatial transformations in a larger area. Even when a deployment itself may be small or temporary, the impact of such an intervention could be far reaching as it starts a process of greening a larger area, improving social coherence in a neighbourhood and marks a decisive momentum change in thinking about the possibility to create a better environment.

The context for urbanisation in a developing and developed context is different. Where rapid urbanisation in a developing context is often related to poverty, social inclusion, economic wellbeing or providing basic infrastructure, and the solutions mostly respond to only one pace of transformation, e.g., rapid, in developed cities the development process of urban areas consists of a range of tempi. In this article it is concluded that in these contexts the response should therefore be more diverse and adjusted to the pace of change a neighbourhood is accustomed to. However, this said, a nature-based approach has benefits in both contexts, as it brings the sustainability and resilience to a higher level, providing people and the natural world an environment that is ecologically rich and benefits human health, both physically as mentally. Therefore, even if urgent problems are social, economic and basic, creating a green urban 
space brings about change and perspective that could be farther reaching than a singular response to an instant problem. Cities and countries in both the developed and developing world can therefore benefit from this approach. Every city has to larger or lesser extent neighbourhoods that transform faster or slower. The results of this research can be used to apply a planning approach that is taking into account these differences hence make the response better suited with increased quality of the urban environment, human health and ecological quality. Overall, applying multiple deployment strategies offer a supportive condition for establishing rich human connections, improving the quality of life, enrich ecological systems and creating a better urban environment.

\section{Acknowledgments}

We are grateful for the support of the research under the Belmont Forum Sustainable Urbanization Global Initiative (SUGI) on Food-Water-Energy Nexus with the project reference M-NEX. The research-by-design workshop was conducted at the Future City Lab, SFC Institute of Keio University sponsored by the Kanpe Real Estates. We thank NPO Town Development Oi for the coordination with local leaders and citizens.

\section{Conflict of Interests}

The authors declare no conflict of interests.

\section{References}

Bird, W. (2007). Natural thinking, investigating the links between the natural environment, biodiversity and mental health. Sandy: Royal Society for the Protection of Birds.

Bodo, T. (2019). Rapid urbanisation: Theories, causes, consequences and coping strategies. Annals of Geographical Studies, 2(3), 32-45.

Borer, M. I. (2013). Being in the city: The sociology of urban experiences. Sociology Compass, 7(11), 965-983.

Brooks, N., Adger, W. N., \& Kelly, P. M. (2005). The determinants of vulnerability and adaptive capacity at the national level and the implications for adaptation. Global Environmental Change, 15(2), 151-163.

Bureau of Crime Statistics and Research. (n.d.). Mapping rates of apprehended domestic violence orders (ADVOs). Sydney: NSW Government. Retrieved from https://www.bocsar.nsw.gov.au/Pages/bocsar_ news/ADVO-Rates.aspx

Cassaignau, M., \& Jung, M. (2018). Building Mixity! Cremorne2025/37.83 ${ }^{\circ} \mathrm{S} / 144.993^{\circ} \mathrm{E}$. Clayton: Monash University Publishing.

Chen, H., Kwong, J. C., Copes, R., Tu, K., Villeneuve, P. J., Van Donkelaar, A., . . Burnett, R. T. (2017). Living near major roads and the incidence of dementia, Parkinson's disease, and multiple sclero- sis: A population-based cohort study. The Lancet, 389(10070), 718-726. https://doi.org/10.1016/ S0140-6736(16)32399-6

Cialdea, D., \& Maccarone, A. (2012). Territory diachronic maps for the Regional Landscape Plan. In M. Campagna, A. De Montis, F. Isola, S. Lai, C. Pira, \& C. Zoppi (Eds.), Planning support tools: Policy analysis, implementation and evaluation (pp. 386-398). Milan: FrancoAngeli.

Condon, P. M. (2008). Design charrettes for sustainable communities. Washington, DC: Island Press.

Davies, C., \& Lafortezza, R. (2019). Transitional path to the adoption of nature-based solutions. Land Use Policy, 80, 406-409.

Davoudi, S., Shaw, K., Haider, L. J., Quinlan, A. E., Peterson, G. D., Wilkinson, C., . . . Porter, L. (2012). Resilience: A bridging concept or a dead end? Planning Theory \& Practice, 13(2), 299-233.

Degen, M. M., \& Rose, G. (2012). The sensory experiencing of urban design: The role of walking and perceptual memory. Urban Studies, 49(15), 3271-3287.

De Hoog, M., Sijmons, D. F., \& Verschuuren, S. (1998). Laagland, eindrapportage HMD-werkgroep Herontwerp [Lowland, Final report HMD working group Redesign]. Amsterdam: Gemeente Amsterdam.

Dennis, M., Barlow, D., Cavan, G., Cook, P. A., Gilchrist, A., Handley, J., . . . Lindley, S. (2018). Mapping urban green infrastructure: A novel landscape-based approach to incorporating land use and land cover in the mapping of human-dominated systems. Land, 7(1). https://doi.org/10.3390/land7010017

DESA. (2013). World economic and social survey 2013: Sustainable development challenges. New York, NY: United Nations.

Diaconu, M., Heuberger, E., Mateus-Berr, R., \& Vosicky, L. M. (Eds.). (2011). Senses and the city: An interdisciplinary approach to urban sensescapes (Vol. 4). Münster: LIT Verlag Münster.

Dovey, K., \& Symons, F. (2014). Density without intensity and what to do about it: Reassembling public/private interfaces in Melbourne's Southbank hinterland. Australian Planner, 51(1), 34-46.

Du Plessis, C. (2012). Towards a regenerative paradigm for the built environment. Building Research \& Information, 40(1), 7-22.

Epstein, L. H., Paluch, R. A., Roemmich, J. N., \& Beecher, M. D. (2007). Family-based obesity treatment, then and now: Twenty-five years of pediatric obesity treatment. Health Psychology, 26(4), 381-391.

European Commission. (2015). Towards an EU research and innovation policy agenda for nature-based solutions \& re-naturing cities: Final report of the Horizon 2020 expert group on 'nature-based solutions and renaturing cities.' Luxembourg: Publications Office of the European Union.

Faivre, N., Fritz, M., Freitas, T., De Boissezon, B., \& Vandewoestijne, S. (2017). Nature-based solutions in the EU: Innovating with nature to address social, eco- 
nomic and environmental challenges. Environmental Research, 159, 509-518.

Flouri, E., Papachristou, E., \& Midouhas, E. (2018). The role of neighborhood greenspace in children's spatial working memory. British Journal of Educational Psychology, 89, 359-373. https://doi.org/10.1111/bjep. 12243

Folke, C., Carpenter, S., Walker, B., Scheffer, M., Chapin, T., \& Rockström, J. (2010). Resilience thinking: Integrating resilience, adaptability and transformability. Ecology and society, 15. http:// www.ecologyandsociety.org/vol15/iss4/art20

Forman, R. T. T. (1995). Some general principles of landscape and regional ecology. Landscape Ecology, 10, 133-142. https://doi.org/10.1007/BF00133027

Frieling, D. H., Hofland, H. J. H., Brouwer, J., Salet, W., De Jong, T., De Hoog, M., . . Marquard, A. (1998). Het Metropolitane debat c Bussum: Toth Uitgeveij.

Garcia, E. J., \& Vale, B. (2017). Unravelling sustainability and resilience in the built environment. London: Routledge.

Girardet, H. (2014). Creating regenerative cities. London: Routledge.

Goldstein, J. (1999). Emergence as a construct: History and issues. Emergence: Complexity and Organization, 1(1), 49-72.

Greater London Authority. (2018). Land area and population density, ward and borough. London Datastore. Retrieved from https://data.london.gov.uk/ dataset/land-area-and-population-density-wardand-borough

Gunderson, L. H., \& Holling, C. S. (2002). Panarchy: Understanding transformations in human and natural systems. Washington, DC: Island Press.

Hauberg, J. (2011). Research by design: A research strategy. Journal of Architectural Education, 5, 46-56.

Houghton, K., Foth, M., \& Miller, E. (2015). Urban acupuncture: Hybrid social and technological practices for hyperlocal placemaking. Journal of Urban Technology, 22(3), 3-19.

Howard, Z., \& Somerville, M. M. (2014). A comparative study of two design charrettes: Implications for codesign and participatory action research. CoDesign, 10(1), 46-62.

Institute for Urban Strategies. (2020). Research on the urban growth history of the Tokyo metropolitan area. The Mori Memorial Foundation. Retrieved from http://mori-m-foundation.or.jp/english/ius2/ tokyo_history2/index.shtml

Jonas, M., \& Rahmann, H. (2014). Tokyo void: Possibilities in absence. Berlin: Jovis Verlag $\mathrm{GmbH}$.

Kaplan, R., \& Kaplan, S. (1989). The experience of nature: A psychological perspective. Cambridge: CUP Archive.

Kaplan, S. (1995). The restorative effects of nature: Toward an integrative framework. Journal of Environmental Psychology, 15, 169-182.

Kindon, S., Pain, R., \& Kesby, M. (Eds.). (2007). Participa- tory action research approaches and methods: Connecting people, participation and place (Vol. 22). London: Routledge.

Kropf, K. (2001). Conceptions of change in the built environment. Urban Morphology, 5(1), 29-42.

Krugman, P. (1996). The self-organizing economy. Oxford: Blackwell.

Kuitert, W. (2013). Urban landscape systems understood by geo-history map overlay. Journal of Landscape Architecture, 8(1), 54-63.

Lafortezza, R., \& Sanesi, G. (2019). Nature-based solutions: Settling the issue of sustainable urbanization. Environmental Research, 172, 394-398.

Landry, C. (2005). Urban acupuncture. Planning Theory \& Practice, 6(1), 117-118.

Lennertz, B., \& Lutzenhiser, A. (2006). The charrette handbook: The essential guide for accelerated collaborative community planning. Chicago, IL: The American Planning Association.

Li, D., \& Sullivan, W. (2016). Impact of views to school landscapes on recovery from stress and mental fatigue. Landscape and Urban Planning, 148, 149-158.

Lindblom, C. E. (1959). The science of "muddling through." Public Administration Review, 19, 79-88.

Mccormick, K. (Ed.). (2020). Cities, nature and innovation: New directions. Lund: Lund University.

Mclntyre, A. (2007). Participatory action research (Vol. 52). London: Sage Publications.

Mennis, J., Mason, M., \& Ambrus, A. (2018). Urban greenspace is associated with reduced psychological stress among adolescents: A geographic ecological momentary assessment (GEMA) analysis of activity space. Landscape and Urban Planning, 174, 1-9. https://doi.org/10.1016/j.landurbplan.2018.02.008

Milburn, L.-A. S., \& Brown, R. D. (2003). The relationship between research and design in landscape architecture. Landscape and Urban Planning, 64, 47-66.

Mostafavi, M., \& Doherty, G. (2016). Ecological urbanism. Zurich: Lars Müller Publishers.

MVRDV. (2006). FARMAX, excursions on density. Rotterdam: 010 Publishers.

Odum E. P., \& Barrett, G. W. (2005). Fundamentals of ecology (5th ed.). Belmont, CA: Thompson Brook/Cole.

Pickett, S. T. A., Cadenasso, M. L., \& McGrath, B. (2013). Resilience in urban ecology and urban design: Linking theory and practice for sustainable cities. New York, NY: Springer.

Pink, S. (2007). Sensing Cittàslow: Slow living and the constitution of the sensory city. The Senses and Society, 2(1), 59-77.

Pinzon Cortes, C. E. (2009). Mapping urban form: Morphology studies in the contemporary urban landscape. Delft: Delft University of Technology.

Pyle, R. M. (1978). The extinction of experience. Horticulture, 56, 64-67.

Rapoport, A. (2016). Human aspects of urban form: 
Towards a man-environment approach to urban form and design. Amsterdam: Elsevier.

Rietveld, R., \& Rietveld, E. (2014). Vacancy studies: Experiments and strategic interventions in architecture. Rotterdam: nai010 Publishers.

Roggema, R. (2012). Swarm planning: The development of a methodology to deal with climate adaptation (Doctoral dissertation). Delft University of Technology, Delft, the Netherlands, and Wageningen University and Research Centre, Wageningen, the Netherlands.

Roggema, R. (Ed.). (2013). The design charrette: Ways to envision sustainable futures. Dordrecht, Heidelberg and London: Springer.

Roggema, R. (2016). Research by design: Proposition for a methodological approach. Urban Science, 1(1), 2-20. http://dx.doi.org/10.3390/urbansci1010002

Roggema, R. (2018). Design with voids: How inverted urbanism increases urban resilience. Architectural Science Review, 61(5), 349-357.

Roggema, R., Van den Dobbelsteen, R., Biggs, C., \& Timmermans, W. (2011). Planning for climate change or: How wicked problems shape the new paradigm of swarm planning. Paper presented at the 3rd World Planning Schools Congress, Perth, Australia.

Roorda, C., Buiter, M., Rotmans, J., Bentvelzen, M., Tillie, N. M. J. D., \& Keeton, R. (2011). Urban development: The state of the sustainable art. Rotterdam: DRIFT.

Rosemann, J. (2001). The conditions of research by design in practice. In M. Van Ouwerkerk \& J. Rosemann (Eds.), Research by design: Proceedings of the international conference proceedings A (pp. 63-68). Delft: Delft University Press.

Rowe, P., Ye Kan, H. (2014). Urban intensities: Contemporary housing types and territories. Basel: Birkhauser. https://doi.org/10.1515/9783038211013

Ryan, C. (2013). Eco-acupuncture: Designing and facilitating pathways for urban transformation, for a resilient low-carbon future. Journal of Cleaner Production, 50, 189-199.

Selener, J. D. (1993). Participatory action research and social change: Approaches and critique. Ithaca, NY: Cornell University.

Sharifi, A. (2019). Urban form resilience: A meso-scale analysis. Cities, 93, 238-252.

Sijmons, D. (1992). Het casco-concept, een benaderingswijze voor de landschapsplanning [The framework model, an approach to landscape planning]. Utrecht: Ministerie van LNV.

Swann, C. (2002). Action research and the practice of design. Design Issues, 18, 49-61.

Thompson, C., Roe, J., Aspinall, P., Mitchell, R., Clow, A.,
\& Miller, D. (2012). More green space is linked to less stress in deprived communities: Evidence from salivary cortisol patterns. Landscape and Urban Planning, 105(3), 221-229.

Tillie, N. (2020). Nature based urbanism in Rotterdam from urban green structure to tidal river: Testing grounds for an urban ecology research agenda at TU Delft. In R. Roggema (Ed.), Nature-driven urbanism: Contemporary urban design thinking (Vol. 2, pp. 111-130). Dordrecht, Heidelberg and London: Springer.

Tree, I. (2018). Wilding, the return of nature to a British farm. London: Picador.

Trivedi, J. K., Sareen, H., \& Dhyani, M. (2008). Rapid urbanization: Its impact on mental health: A South Asian perspective. Indian Journal of Psychiatry, 50(3), 161-165.

Ulrich, R. S. (1983). Aesthetic and affective response to natural environment. In I. Altman \& J. F. Wohlwill (Eds.), Behavior and the natural environment (Vol. 6, pp. 85-125). Boston, MA: Springer Science \& Business Media.

Ulrich, R. S., Simons, R. F., Losito, B. D., Fiorito, E., Miles, M. A., \& Zelson, M. (1991). Stress recovery during exposure to natural and urban environments. Journal of Environmental Psychology, 11(3), 201-230.

United Nations. (2017). New urban agenda. New York, NY: United Nations.

United Nations. (2020). Sustainable development goals report 2020: Finding transformative pathways in turbulent times. New York, NY: United Nations.

Van Bree, P., \& Kessels, G. (2014). Mapping memory landscapes in nodegoat. In L. M. Aiello \& D. McFarland (Eds.), International conference on social informatics (pp. 274-278). Cham: Springer.

Vanderhaegen, S., \& Canters, F. (2017). Mapping urban form and function at city block level using spatial metrics. Landscape and Urban Planning, 167, 399-409.

Wendell Cox Consultancy. (2001). Tokyo: Wards (Ku) ranked by density. Demographia. Retrieved from http://demographia.com/db-tokyo-wardr.htm

Wilson, E. O. (1984). Biophilia. Cambridge, MA: Harvard University Press.

Wolfram, M., \& Frantzeskaki, N. (2016). Cities and systemic change for sustainability: Pre-vailing epistemologies and an emerging research agenda. Sustainability, 8(2). https://doi.org/10.3390/su8020144

World Economic Forum. (2020). Global risks 2020: An unsettled world. Geneva: World Economic Forum.

Zari, M. P. (2018). Regenerative urban design and ecosystem biomimicry. London and New York, NY: Routledge. 


\section{About the Authors}

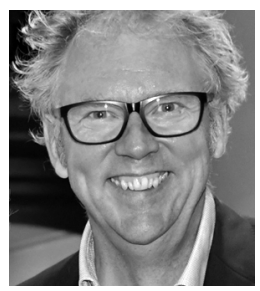

Rob Roggema (PhD) is Landscape Architect and Director/Founder of Cittaideale, office for adaptive design and planning, and Distinguished Visiting Professor at Western Sydney University. Since 2019 he is Professor of Spatial Transformation at the Hanze University Groningen. Between 2010 and 2013 he was Inaugural Visiting Research Fellow of the Victorian Centre for Climate Change Adaptation Research, University of Melbourne. From 2014 to 2016 he was appointed as Professor of Design for Urban Agriculture at VHL University and between 2016 and 2018 he was Professor of Sustainable Urban Environments at the University of Technology Sydney. Before 2010 he worked for the province of Groningen and municipalities such as Almere, Breda and Rotterdam. Rob is currently Series Editor of Contemporary Urban Design Thinking (Springer).

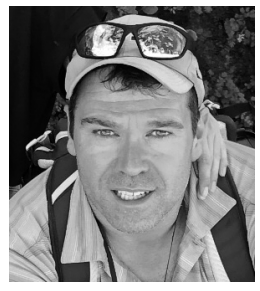

Nico Tillie (PhD) is Landscape Architect and Plant Specialist and specializes in synergetic urban landscape planning at TUDelft, the Netherlands where he leads the Urban Ecology \& Ecocities Lab. He works on issues ranging from energy transition, low carbon cities, climate adaptation, urban agriculture to biodiversity. For many years he worked for the city of Rotterdam in urban green and sustainability related projects. Apart from being a Senior Fellow of the Global Cities Institute of the University of Toronto in Canada, he was in the advisory board of the sustainable development site of the Olympic Games Paris 2024 and he is currently in the scientific Board of NL Greenlabel. In 2021, he is Conference Chair of the Ecocities World Summit in Rotterdam.

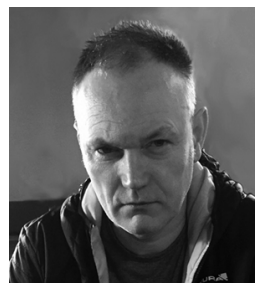

Greg Keeffe is Professor of Architecture and Urbanism and Head of the School of Natural and Built Environment at Queens University Belfast. Previously he held the prestigious Downing Chair of Sustainable Architecture at Leeds School of Architecture. In 2013 and 2015 he was Strauch Visiting Professor of Sustainable Architecture at Cornell University, USA. His work focuses around the idea of the productive city, making a synergy between urban form, landscape and new biological technologies. $\mathrm{He}$ is an Expert Advisor to the Horizon Programme at the EU, regarding Urbanism and Sustainability, and a peer evaluator for the Economic and Social Research Council UK. Greg is a Fellow of the Royal Society of Arts.

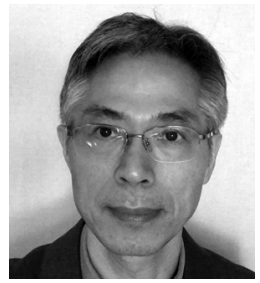

Wanglin Yan (PhD) is Professor, Faculty of Environmental Information Studies, Keio University, and Head of Program for Environmental Design and Governance, Graduate School of Media and Governance of the University. Yan is a distinguished scholar in Environmental and Geo-informational Science for urban and regional planning by multi-disciplinary and transdisciplinary approaches. He has led the sub-regional node of Asia-Pacific Adaptation Network of UNEP and devoted to climate change adaptation and disaster risk reduction in Japan and northeast Asian countries. Recently he is leading the international consortium of M-NEX and studying on co-creative design for community-based sustainable urbanisation. 